\title{
Hubungan Hasil Belajar Kalkulus Diferensial dan Kalkulus Integral Terhadap Hasil Belajar Kalkulus Lanjut Mahasiswa Pendidikan Matematika Universitas Sanata Dharma
}

\author{
Silvia $^{1,{ }^{*}}$, Yohana Zettirareska Fernandez ${ }^{1}$, Yulvani Anggraeni Christine Limbong ${ }^{1}$ \\ ${ }^{1}$ Program Studi Pendidikan Matematika, Fakultas Keguruan dan IImu Pendidikan, Universitas Sanata \\ Dharma, Yogyakarta 55281 \\ *email korespondensi: silvia.avui@gmail.com
}

Received : 6 Juli 2020; Revised : 28 September 2020; Accepted : 20 Oktober 2020; Published : 31 Oktober 2020

\section{ABSTRAK}

Mata kuliah Kalkulus Lanjut di program studi Pendidikan Matematika Universitas Sanata Dharma (USD) dapat ditempuh mahasiswa dengan syarat telah lulus dari mata kuliah Kalkulus Diferensial dan Kalkulus Integral. Tujuan dari penelitian ini untuk menguji signifikansi kontribusi kemampuan Kalkulus Diferensial atau Kalkulus Integral terhadap hasil belajar Kalkulus Lanjut pada mahasiswa Pendidikan Matematika USD. Populasi pada penelitian ini adalah mahasiswa Program Studi Pendidikan Matematika USD. Sampel pada penelitian ini adalah mahasiswa Program Studi Pendidikan Matematika USD angkatan 2017 dengan teknik pengambilan sampel menggunakan cluster sampling. Teknik pengumpulan data dengan menggunakan dokumentasi. Teknik analisis data menggunakan uji regresi linier berganda dan uji korelasi. Seluruh analisis statistik dilakukan dengan menggunakan software SPSS. Berdasarkan hasil analisis data tersebut, disimpulkan ada kontribusi yang signifikan antara hasil belajar Kalkulus Diferensial atau hasil belajar Kalkulus Integral terhadap hasil belajar Kalkulus Lanjut. Selain itu, hasil belajar Kalkulus Integral memiliki pengaruh atau kontribusi yang lebih domain terhadap hasil belajar Kalkulus Lanjut dari pada hasil belajar Kalkulus Diferensial dan terdapat error yang cukup besar yakni sebesar $46.7 \%$ sehingga menunjukkan ada pengaruh yang besar di luar hasil belajar Kalkulus Diferensial dan hasil belajar Kalkulus Integral. Hal ini didukung dengan hasil angket yang memperoleh bahwa ada faktor lain seperti dosen memberi pengaruh yang besar dalam hasil belajarnya.

Kata-kata kunci: cluster sampling; hasil belajar; Kalkulus Diferensial; Kalkulus Integral; Kalkulus Lanjut

\section{PENDAHULUAN}

Mata kuliah Kalkulus Lanjut di program studi Pendidikan Matematika Universitas Sanata Dharma dapat ditempuh mahasiswa dengan syarat telah lulus dari mata kuliah Kalkulus Diferensial dan Kalkulus Integral.

Kalkulus adalah bidang ilmu yang mempelajari bagaimana sesuatu dapat berubah dan bagaimana akibat yang ditimbulkan dari perubahan tersebut. Melalui Kalkulus, dapat dilakukan penyesuaian atau mendekati sebuah kontrol perilaku dengan yang dikehendaki pada sistem dapat. Dasar ilmu Kalkulus yaitu mempelajari perubahan seketika, atau mempelajari perubahan yang terjadi pada interval waktu yang sangat kecil. Materi-materi tersebut dipelajari dalam mata kuliah yang berbeda yakni:

1. Kalkulus Diferensial, yang mencakup fungsi, limit dan kekontinuan, turunan dan aturan menentukan turunan, dan penggunaan turunan.

2. Kalkulus Integral, yang mencakup garis besar materi dan kerangka kegiatan anti turunan (derivatif), penerapan integral tentu, dan metode pengintegralan.

3. Kalkulus Lanjut, yang mencakup barisan bilangan real dan konsep kekonvergenan, fungsi peubah banyak, turunan fungsi peubah banyak, dan integral fungsi peubah banyak.

Berdasarkan cakupan materi Kalkulus Lanjut, terlihat bahwa Kalkulus Lanjut mempelajari lebih dalam konsep-konsep limit, turunan, dan integral yang telah dipelajari di Kalkulus Diferensial dan Kalkulus Integral.

Menurut Ausubel (dikutip oleh Soekamto, 1997) belajar semestinya melalui proses di mana materi yang dipelajari akan diserap lalu dibandingkan dengan konsep dasar yang dimiliki. Selain itu, teori pembelajaran bermakna Ausubel menekankan pada hubungan materi yang dipelajari dengan struktur kognitif siswa. Struktur kognitif merupakan konsep yang telah dipelajari siswa. Berdasarkan pendapat 
Ausubel dapat dimaknai bahwa konsep-konsep pada Kalkulus Diferensial dan Kalkulus Integral yang telah dipelajari menjadi struktur kognitif awal mahasiswa dalam mempelajari Kalkulus Lanjut, sehingga peneliti menduga semakin tinggi pemahaman konsep di Kalkulus Diferensial dan Kalkulus Integral berdampak pada semakin tinggi pemahaman konsep Kalkulus Lanjut. Dugaan peneliti juga didukung oleh pendapat Septian (2014) yaitu faktor penting yang mempengaruhi hasil belajar siswa atau mahasiswa dapat dilihat dari penguasaan konsep dari kemampuan prasyarat suatu mata kuliah.

Selain itu, didukung oleh penelitian lain yang dilakukan oleh Rejeki (2015) tentang pengaruh kemampuan siswa dalam mata kuliah Kalkulus I dan II terhadap hasil belajar mata kuliah Analisis Vektor. Mata kuliah Kalkulus I dan II merupakan kecakapan prasyarat untuk mata kuliah Analisis Vektor. Berdasarkan penelitian diperoleh bahwa kemampuan mahasiswa dalam mata kuliah Kalkulus I dan II berpengaruh terhadap hasil belajar mahasiswa dalam mata kuliah Analisis Vektor.

Menurut Suprijono (2012), hasil belajar adalah pola-pola perilaku, nilai-nilai, pemahamanpemahaman, sikap - sikap, apresiasi dan keahlian. Menurut Arsyad (2005) hasil belajar adalah rangkaian perkembangan perilaku individu karena terjadi perubahan kompetensi pengetahuan, keterampilan, dan spiritual. Selanjutnya Supratiknya (2012) mengemukakan bahwa kemampuan baru yang dicapai siswa setelah mengikuti proses pembelajaran pada mata pelajaran tertentu merupakan wujud dari hasil belajar yang menjadi objek penilaian kelas. Peneliti akan menggunakan data hasil belajar Kalkulus Diferensial, Kalkulus Integral, dan Kalkulus Lanjut untuk mengetahui apakah terdapat hubungan yang erat antara hasil belajar Kalkulus Diferensial dan Kalkulus Integral pada hasil belajar Kalkulus Lanjut. Apakah jika mahasiswa memperoleh hasil belajar Kalkulus Diferensial dan Kalkulus Integral yang baik maka hasil belajar Kalkulus Lanjut sudah dapat dipastikan baik? Berdasarkan penjabaran di atas, tujuan penelitian ini yaitu:

1. Menguji signifikansi kontribusi kemampuan Kalkulus Diferensial terhadap hasil belajar Kalkulus Lanjut pada mahasiswa Pendidikan Matematika Universitas Sanata Dharma.

2. Menguji signifikansi kontribusi kemampuan Kalkulus Integral terhadap hasil belajar Kalkulus Lanjut pada mahasiswa Pendidikan Matematika Universitas Sanata Dharma.

3. Menguji signifikansi kontribusi kemampuan Kalkulus Diferensial dan Kalkulus Integral terhadap hasil belajar Kalkulus Lanjut pada mahasiswa Pendidikan Matematika Universitas Sanata Dharma.

\section{EKSPERIMEN}

Jenis Penelitian yang digunakan adalah penelitian kuantitatif dengan metode korelasional. Menurut Sugiyono (2013), penelitian kuantitatif adalah penelitian yang berlandaskan pada filsafat positivisme yang digunakan untuk meneliti subjek penelitian tertentu, pengumpulan data menggunakan instrumen penelitian, analisis data bersifat kuantitatif / statistik, dengan tujuan untuk menguji asumsi atau dugaan yang telah ditetapkan. Menurut Winarni (2011) penelitian korelasional adalah penelitian yang digunakan untuk melihat hubungan antar variabel yang ada.

Populasi dalam penelitian ini adalah seluruh mahasiswa Pendidikan Matematika Fakultas Keguruan dan IImu Pendidikan Universitas Sanata Dharma dan sampel penelitian ini adalah seluruh mahasiswa Pendidikan Matematika Fakultas Keguruan dan Ilmu Pendidikan Universitas Sanata Dharma Angkatan 2017 dengan jumlah 87 mahasiswa yang terbagi ke dalam 3 kelas yakni 17A, 17B dan 17C. Mahasiswa yang menjadi sampel adalah mahasiswa yang mengikuti perkuliahan Kalkulus Diferensial tahun akademik 2017/2018, Kalkulus Integral tahun akademik 2018/2019 dan Kalkulus Lanjut tahun akademik 2019/2020 hingga selesai dan memperoleh nilai final atau akhir. Teknik yang digunakan untuk mengambil sampel pada penelitian ini adalah menggunakan cluster sampling atau pengambilan sampel berkelompok.

Objek yang diteliti dalam penelitian ini adalah hasil belajar Kalkulus Diferensial $\left(X_{1}\right)$ dan Kalkulus Integral $\left(X_{2}\right)$ sebagai variabel bebas (independen) dan hasil belajar Kalkulus Lanjut $(Y)$ sebagai variabel terikat (dependen).

Teknik pengumpulan data dalam penelitian yakni dokumentasi untuk memperoleh hasil belajar Kalkulus Diferensial, Kalkulus Integral dan Kalkulus Lanjut. Jenis dan bentuk data adalah data sekunder berdasarkan sumbernya, peneliti mengambil data secara langsung melalui Kaprodi Pendidikan Matematika Universitas Sanata Dharma dan data termasuk data rasio berdasarkan tipe skala pengukuran. Teknik analisis data menggunakan uji regresi berganda. Menurut Sufren \& Natanael (2014) sebelum menguji regresi berganda dilakukan uji prasyarat yang mencakup uji normalitas, uji linearitas, uji multikolinearitas, uji autokorelasi, uji heterokedastiditas. Peneliti menambahkan analisis korelasi sebagai uji prasyarat. Seluruh analisis statistik dilakukan menggunakan aplikasi SPSS. Peneliti juga menghitung sumbangan efektif dan sumbangan relatif dari setiap variabel independen. Selain itu, peneliti juga membagikan kuesioner kepada 
beberapa mahasiswa untuk memperoleh informasi mengenai hal-hal lain yang bisa mempengaruhi hasil belajar Kalkulus Lanjut.

\section{HASIL DAN DISKUSI}

Data hasil belajar Kalkulus Diferensial, Kalkulus Integral dan Kalkulus Lanjut dapat disajikan dalam Tabel 1 berikut.

Tabel 1. Hasil Belajar Kalkulus Diferensial, Kalkulus Integral dan Kalkulus Lanjut

\begin{tabular}{cccc}
\hline & \multicolumn{3}{c}{ Hasil Belajar } \\
\cline { 2 - 4 } & Kalkulus Diferensial & Kalkulus Integral & Kalkulus Lanjut \\
\hline Nilai Tertinggi & 89,05 & 94,8 & 95,33 \\
Nilai Terendah & 50 & 39,33 & 20,35 \\
Mean & 72,1695 & 66,2424 & 65,1987 \\
Median & 72,6 & 66,4 & 63,93 \\
Standar Deviasi & 9,30372 & 12,8845 & 12,7838 \\
\hline
\end{tabular}

Berdasarkan Tabel 1 diketahui bahwa hasil belajar tertinggi pada mata kuliah Kalkulus Lanjut lebih tinggi dibandingkan dengan hasil belajar tertinggi pada mata kuliah Kalkulus Diferensial dan Kalkulus Integral. Namun untuk hasil belajar terendah pada mata kuliah Kalkulus Lanjut lebih rendah dibandingkan dengan hasil belajar terendah pada mata kuliah Kalkulus Diferensial dan Kalkulus Integral, hal yang sama juga terjadi pada nilai mean dan median. Nilai mean dan median pada Kalkulus Lanjut lebih rendah jika dibandingkan dengan nilai mean dan median pada mata kuliah Kalkulus Diferensial dan Kalkulus Integral. Untuk standar deviasi pada nilai Kalkulus Lanjut berada diantara standar deviasi Kalkulus Diferensial dan Kalkulus Integral.

Sebelum analisis data menggunakan uji regresi linier berganda berikut adalah pembahasan mengenai uji prasyarat analisis regresi linier berganda uji prasyarat yang mencakup uji normalitas, uji linearitas, uji multikolinearitas, uji autokorelasi, dan uji heterokedastiditas. Seluruh analisis statistik dilakukan dengan menggunakan software SPSS.

One-Sample Kolmogorov-Smirnov Test

\begin{tabular}{|c|c|c|}
\hline & & $\begin{array}{l}\text { Unstandardiz } \\
\text { ed Residual }\end{array}$ \\
\hline 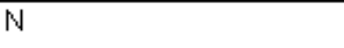 & & 87 \\
\hline \multirow[t]{2}{*}{ Normal Parameters ${ }^{a, . b}$} & Mean & .0000000 \\
\hline & Std. Deviation & 8.73271705 \\
\hline \multirow[t]{3}{*}{ Most Extreme Differences } & Absolute & .088 \\
\hline & Positive & .048 \\
\hline & Negative & -.088 \\
\hline Kolmogorov-Smirnov $Z$ & & .819 \\
\hline Asymp. Sig. (2-tailed) & & .514 \\
\hline
\end{tabular}

a. Test distribution is Normal.

b. Calculated from data.

Gambar 1. Output SPSS Uji Normalitas

Uji normalitas yang digunakan dalam penelitian ini adalah Kolmogorov - Smirnov. Dari output SPSS diperoleh nilai signifikansi Asiymp.Sig (2 - tailed) sebesar 0,514, karena nilai tersebut lebih besar daripada 0,05 maka dapat disimpulkan data yang digunakan dalam penelitian berdistribusi normal. ANOVA Table

\begin{tabular}{|c|c|c|c|c|c|c|c|}
\hline & & & $\begin{array}{c}\text { Sum of } \\
\text { Squares }\end{array}$ & df & Mean Square & $\mathrm{F}$ & Sig. \\
\hline \multirow{5}{*}{ KALJUT* * KALDIF } & Between Groups & (Combined) & 13897.648 & 81 & 171.576 & 5.465 & .032 \\
\hline & & Linearity & 5868.445 & 1 & 5868.445 & 186.908 & .000 \\
\hline & & Deviation from Linearity & 8029.203 & 80 & 100.365 & 3.197 & .096 \\
\hline & Within Groups & & 156.988 & 5 & 31.398 & & \\
\hline & Total & & 14054.636 & 86 & & & \\
\hline
\end{tabular}

Gambar 2. Output SPSS Uji Linearitas Kalkulus Lanjut dan Kalkulus Diferensial 
Jurnal Sains dan Edukasi Sains, Vol.3, No.2, Agustus 2020: 58-65

\begin{tabular}{|c|c|c|c|c|c|c|c|}
\hline \multicolumn{8}{|c|}{ ANOVA Table } \\
\hline & & & $\begin{array}{l}\text { Sum of } \\
\text { Squares }\end{array}$ & df & Mean Square & $\mathrm{F}$ & Sig. \\
\hline \multirow[t]{5}{*}{ KALJUT * KALIN } & Between Groups & (Combined) & 14051.536 & 85 & 165.312 & 53.326 & .109 \\
\hline & & Linearity & 6709.823 & 1 & 6709.823 & 2164.424 & .014 \\
\hline & & Deviation from Linearity & 7341.713 & 84 & 87.401 & 28.194 & 149 \\
\hline & Within Groups & & 3.100 & 1 & 3.100 & & \\
\hline & Total & & 14054.636 & 86 & & & \\
\hline
\end{tabular}

Gambar 3. Output SPSS Uji Linearitas Kalkulus Lanjut dan Kalkulus Integral

Untuk variabel hasil belajar Kalkulus Diferensial dan Kalkulus Lanjut dari output SPSS diperoleh nilai Deviation From Linearity Sig. $=0,096$, karena nilai tersebut lebih besar daripada 0.05 maka dapat disimpulkan ada hubungan yang linear secara signifikan antara variabel independen dengan variabel dependen atau ada hubungan yang linear secara signifikan antara hasil belajar Kalkulus Diferensial dengan hasil belajar Kalkulus Lanjut. Selain itu, untuk variabel hasil belajar Kalkuluas Integral dan Kalkulus Lanjut dari output SPSS diperoleh nilai Deviation From Linearity Sig. $=0,149$, karena nilai tersebut lebih besar daripada 0.05 maka dapat disimpulkan ada hubungan yang linear secara signifikan antara variabel independen dengan variabel dependen atau ada hubungan yang linear secara signifikan antara hasil belajar Kalkulus Integral dengan hasil belajar Kalkulus Lanjut.

Coeficients $^{a}$

\begin{tabular}{|c|c|c|c|c|c|c|c|c|}
\hline \multirow{2}{*}{\multicolumn{2}{|c|}{ Madel }} & \multicolumn{2}{|c|}{ Unstandardized Coefficients } & \multirow{2}{*}{$\begin{array}{c}\begin{array}{c}\text { Standardized } \\
\text { Coefficients }\end{array} \\
\text { Beta }\end{array}$} & \multirow[b]{2}{*}{$t$} & \multirow[b]{2}{*}{ Siq. } & \multicolumn{2}{|c|}{ Collinearity Statistics } \\
\hline & & $\mathrm{B}$ & Std. Error & & & & Tolerance & VIF \\
\hline \multirow[t]{3}{*}{1} & (Constant) & 2.205 & 7.455 & & .296 & .768 & & \\
\hline & KALDIF & .447 & .141 & .325 & 3.174 & .002 & .529 & 1.890 \\
\hline & KALIN & .464 & .102 & .468 & 4.566 & .000 & .529 & 1.890 \\
\hline
\end{tabular}

a. Dependent Variable: KALJUT

Gambar 4. Output SPSS Uji Multikolinearitas

Dari output SPSS diperoleh nilai tolerance dan VIF untuk variabel Kalkulus diferensial dan Kalkulus Integral berturut - turut adalah 0,529 dan 1,890, karena nilai tolerance lebih besar daripada 0,10 atau VIF lebih kecil daripada 10,00 maka dapat disimpulkan tidak terjadi multikolinearitas dalam model regresi atau tidak ada korelasi (hubungan kuat) antar variabel bebas yakni hasil belajar Kalkulus Diferensial dan hasil belajar Kalkulus Integral atau tidak terjadi multikolinearitas dalam model regresi.

Coefficients $^{\Xi}$

\begin{tabular}{|c|c|c|c|c|c|c|c|c|}
\hline \multirow{2}{*}{\multicolumn{2}{|c|}{ Madel }} & \multicolumn{2}{|c|}{ Unstandardized Coefficients } & \multirow{2}{*}{$\begin{array}{c}\begin{array}{c}\text { Standardized } \\
\text { Coefficients }\end{array} \\
\text { Beta }\end{array}$} & \multirow[b]{2}{*}{$t$} & \multirow[b]{2}{*}{ Siq. } & \multicolumn{2}{|c|}{ Collinearity Statistics } \\
\hline & & $\mathrm{B}$ & Std. Error & & & & Tolerance & VIF \\
\hline \multirow[t]{3}{*}{1} & (Constant) & 8.475 & 4.968 & & 1.706 & .092 & & \\
\hline & KALDIF & .004 & .094 & .006 & .041 & .967 & .529 & 1.890 \\
\hline & KALIN & -.035 & .068 & -.076 & -.511 & .611 & .529 & 1.890 \\
\hline
\end{tabular}

a. Dependent Variable: Abs_RES

Gambar 5. Output SPSS Uji Heteroskedastitas

Dari output SPSS diperoleh nilai Sig. untuk variabel hasil belajar Kalkulus Diferensial adalah 0,967 dan nilai Sig. untuk variabel hasil belajar Kalkulus Integral adalah 0,611, karena nilai Sig. keduanya lebih besar daripada 0,05 maka dapat disimpulkan tidak terdapat gejala heteroskedastitas dalam model regresi yang dihasilkan.

Dari hasil uji prasyarat analisis regresi linier berganda yaitu uji normalitas, uji linieritas, uji multikolinieritas, uji autokorelasi, dan uji heteroskedastisitas (Gambar 1-5) dapat disimpulkan bahwa uji regresi linier berganda baik untuk dilihat.

Tabel 2. Ringkasan Hasil Analisis Regresi

\begin{tabular}{cccc}
\hline Variabel & Koefisien Regresi & $\boldsymbol{t}_{\text {hitung }}$ & Sig. \\
\hline Konstanta & 2.205 & & \\
$\boldsymbol{X}_{\mathbf{1}}$ & 0.447 & 3,174 & 0,002 \\
$\boldsymbol{X}_{2}$ & 0.464 & 4,566 & 0,000 \\
$F_{\text {hitung }}=48,006$ & & & 0,000 \\
$R^{2}=0.533$ & & & \\
\hline
\end{tabular}


Dari output SPSS diperoleh model regresi adalah sebagai berikut

$$
Y=2.205+0.447 X_{1}+0.464 X_{2}
$$

Keterangan :

$Y=$ nilai Kalkulus Lanjut

$X_{1}=$ nilai Kalkulus Differensial

$X_{2}=$ nilai Kalkulus Integral

Selanjutnya dilakukan analisis dengan uji $\mathrm{t}$ dan uji $\mathrm{F}$ untuk mengetahui kontribusi kemampuan Kalkulus Diferensial terhadap hasil belajar mata kuliah Kalkulus Lanjut, kontribusi kemampuan Kalkulus Integral terhadap hasil belajar mata kuliah Kalkulus Lanjut, dan kontribusi kemampuan Kalkulus Diferensial dan Kalkulus Integral terhadap hasil belajar mata kuliah Kalkulus Lanjut.

1. Kontribusi kemampuan Kalkulus Diferensial terhadap hasil belajar Kalkulus Lanjut

Dari output SPSS diperoleh nilai Sig. dan $t_{\text {hitung }}$ pada hasil belajar Kalkulus Diferensial berturut - turut adalah 0,002 dan 3,174. Berdasarkan dasar pengambilan keputusan uji t parsial dalam analisis regresi jika nilai Sig. $=0,002<0,05$ atau $t_{\text {hitung }}=3,174>t_{\text {tabel }}=t_{(0,025 ; 84)}=1,988$ maka ada pengaruh yang signifikan antara hasil belajar Kalkulus Diferensial terhadap hasil belajar Kalkulus Lanjut. Sama artinya dengan kemampuan mahasiswa dalam penguasaan konsep Kalkulus Diferensial memberikan kontribusi yang signifikan untuk hasil belajar Kalkulus Lanjut.

2. Kontribusi kemampuan Kalkulus Integral terhadap hasil belajar Kalkulus Lanjut

Dari output SPSS diperoleh nilai Sig. dan $t_{\text {hitung }}$ pada hasil belajar Kalkulus Integral berturut turut adalah 0,000 dan 4,566. Berdasarkan dasar pengambilan keputusan uji t parsial dalam analisis regresi jika nilai Sig. lebih kecil daripada 0,05 atau $t_{\text {hitung }}$ lebih besar daripada $t_{\text {tabel }}=t_{(0,025 ; 84)}=$ 1,988 maka ada pengaruh yang signifikan antara hasil belajar Kalkulus Integral terhadap hasil belajar Kalkulus Lanjut. Sama artinya dengan kemampuan mahasiswa dalam penguasaan konsep Kalkulus Integral memberikan kontribusi yang signifikan untuk hasil belajar Kalkulus Lanjut.

3. Kontribusi kemampuan Kalkulus Diferensial dan Kalkulus Integral terhadap hasil belajar Kalkulus Lanjut.

Dari output SPSS diperoleh nilai Sig. dan $F_{\text {hitung }}$ pada hasil belajar Kalkulus Integral berturut turut adalah 0,000 dan 48,006. Berdasarkan dasar pengambilan keputusan uji F simultan dalam analisis regresi jika nilai Sig. lebih kecil daripada 0,05 atau $F_{\text {hitung }}$ lebih besar daripada $F_{\text {tabel }}=F_{(0,05 ; 2 ; 85)}=$ 0,051 maka ada pengaruh yang signifikan antara hasil belajar Kalkulus Diferensial dan hasil belajar Kalkulus Integral terhadap hasil belajar Kalkulus Lanjut. Sama artinya dengan kemampuan mahasiswa dalam penguasaan konsep pada Kalkulus Diferensial dan Kalkulus Integral memberikan kontribusi yang signifikan untuk hasil belajar Kalkulus Lanjut. Selain itu dari output SPSS diperoleh nilai koefisien determinasi $\left(R^{2}\right)$ sebesar 0,533 yang berarti kontribusi atau sumbangan pengaruh hasil belajar Kalkulus Diferensial dan hasil belajar Kalkulus Integral secara simultan (bersama - sama) terhadap hasil belajar Kalkulus Lanjut sebesar 0,533 atau 53,3\%, sedangkan sisanya yakni 0,467 atau 46,7\% dipengaruhi oleh variabel lain selain hasil belajar Kalkulus Diferensial dan hasil belajar Kalkulus Integral.

Sehingga dari hasil penelitian di atas, faktor kemampuan prasyarat secara simultan memberikan kontribusi yang cukup pada hasil belajar mata kuliah Kalkulus Lanjut. Hal ini sejalan dengan pendapat yang dikemukakan oleh Svinicki (dikutip dari Rejeki, 2015) bahwa setiap siswa atau mahasiswa yang akan membangun informasi atau pengetahuan baru, akan dipengaruhi informasi atau pengetahuan yang sebelumnya dimiliki oleh siswa atau mahasiswa tersebut. Oleh karena itu, kemampuan Kalkulus Diferensial dan Kalkulus Integralyang tinggi akan berdampak positif pada cara mahasiswa menerima, mengorganisasi, dan menghubungkan informasi-informasi baru dalam materi mata kuliah Kalkulus Lanjut, yang akhirnya akan memberikan pengaruh positif terhadap hasil belajar Kalkulus Lanjut.

Selanjutnya kita akan menentukan sumbangan efektif $(S E)$ serta sumbangan relatif $(S R)$ pada hasil belajar Kalkulus Diferensial $\left(X_{1}\right)$ dan hasil belajar Kalkulus Integral $\left(X_{2}\right)$. Sumbangan efektif adalah ukuran yang digunakaan untuk melihat besar kontribusi suatu variabel bebas terhadap variabel terikat dalam analisis regresi. Jumlah dari seluruh sumbangan efektif pada setiap variabel bebas sama dengan jumlah nilai $R^{2}$. Sementara itu, sumbangan relatif adalah ukuran yang digunakan untuk melihat besarnya kontribusi suatu variabel bebas terhadap $R^{2}$ Jumlah dari seluruh sumbangan relatif pada setiap variabel bebas sama dengan $100 \%$ atau 1. 
Rumus mengitung $S E$ dan $S R$ (SPSS, 2020) adalah sebagai berikut:

$$
\begin{aligned}
& S E(X)=\operatorname{Beta}_{x} \times r_{x y} \times 100 \% \\
& S R(X)=\frac{S E(X) \%}{R^{2}}
\end{aligned}
$$

Keterangan :

$S E(X)=$ Sumbangan efektif pada variabel $X$

$S R(X)=$ Sumbangan relatif pada variabel $X$

Beta $_{x}=$ Koefisien regresi

$r_{x y}=$ Koefisien korelasi

$R^{2}=$ Koefisien determinasi

Berikut adalah ringkasan dari analisis korelasi dan regresi yang telah dilakukan.

Tabel 3. Ringkasan Hasil Analisis Korelasi dan Regresi

\begin{tabular}{cccc}
\hline Variabel & $\begin{array}{c}\text { Koefisien Regresi } \\
(\text { Beta })\end{array}$ & $\begin{array}{c}\text { Koefisien Korelasi } \\
(\boldsymbol{r})\end{array}$ & \multirow{2}{*}{$\boldsymbol{R}^{\mathbf{2}}$} \\
\hline$X_{1}$ & 0,325 & 0,646 & \multirow{2}{*}{0,533} \\
\hline$X_{2}$ & 0,468 & 0,691 & \\
\hline
\end{tabular}

1. Sumbangan Efektif Hasil Belajar Kalkulus Diferensial $\left(X_{1}\right)$

$$
\begin{aligned}
S E\left(X_{1}\right) & =\text { Beta }_{X_{1}} \times r_{X_{1} Y} \times 100 \% \\
& =0,325 \times 0,646 \times 100 \% \\
& =20,995 \%
\end{aligned}
$$

2. Sumbangan Efektif Hasil Belajar Kalkulus Integral $\left(X_{2}\right)$

$$
\begin{aligned}
\operatorname{SE}\left(X_{2}\right) & =\text { Beta }_{X_{2}} \times r_{X_{2} Y} \times 100 \% \\
& =0,468 \times 0,691 \times 100 \% \\
& =32,3388 \%
\end{aligned}
$$

3. Sumbangan Relatif Hasil Belajar Kalkulus Diferensial $\left(X_{1}\right)$

$$
\begin{aligned}
S R\left(X_{1}\right) & =\frac{S E\left(X_{1}\right) \%}{R^{2}} \\
& =\frac{20,995 \%}{0,533} \\
& =39,39 \%
\end{aligned}
$$

4. Sumbangan Relatif Hasil Belajar Kalkulus Integral $\left(X_{2}\right)$

$$
\begin{aligned}
S R\left(X_{2}\right) & =\frac{S E\left(X_{2}\right) \%}{R^{2}} \\
& =\frac{32,3388 \%}{0,533} \\
& =60,673 \%
\end{aligned}
$$

Berdasarkan hasil perhitungan di atas diketahui sumbangan efektif hasil belajar Kalkulus Diferensial $\left(X_{1}\right)$ terhadap hasil belajar Kalkulus Lanjut $(Y)$ sebesar 20,995\%. Sementara itu, sumbangan efektif hasil belajar Kalkulus Integral $\left(X_{2}\right)$ terhadap hasil belajar Kalkulus Lanjut $(Y)$ sebesar 32,3388\%. Dengan demikian dapat disimpulkan bahwa hasil belajar Kalkulus Integral $\left(X_{2}\right)$ memiliki pengaruh yang lebih domain terhadap hasil belajar Kalkulus Lanjut $(Y)$ dari pada hasil belajar Kalkulus Diferensial $\left(X_{1}\right)$. Jumlah sumbangan efektif hasil belajar Kalkulus Diferensial $\left(X_{1}\right)$ dan sumbangan efektif hasil belajar Kalkulus Integral $\left(X_{2}\right)$ sama dengan koefisien determinan atau $R^{2}$ yakni $53,33 \%$.

Selanjutnya berdasarkan hasil perhitungan di atas diketahui sumbangan relatif hasil belajar Kalkulus Diferensial $\left(X_{1}\right)$ terhadap hasil belajar Kalkulus Lanjut $(Y)$ sebesar 39,39\%. Sementara sumbangan relatif hasil belajar Kalkulus Integral $\left(X_{2}\right)$ terhadap hasil belajar Kalkulus Lanjut $(Y)$ sebesar $60,673 \%$. Jumlah sumbangan relatif hasil belajar Kalkulus Diferensial $\left(X_{1}\right)$ dan sumbangan relatif hasil belajar Kalkulus Integral $\left(X_{2}\right)$ sama dengan $100 \%$.

Berdasarkan hasil SPSS diperoleh persamaan regresi (1), dengan $Y$ adalah hasil belajar Kalkulus Lanjut, $X_{1}$ adalah hasil belajar Kalkulus Diferensial, dan $X_{2}$ adalah hasil belajar Kalkulus Integral dan diperoleh error dengan besar $46,7 \%$. Peneliti ingin mencari tahu pengaruh variabel lain selain hasil belajar Kalkulus Diferensial dan hasil belajar Kalkulus Integral terhadap hasil belajar Kalkulus Lanjut dengan menyebarkan angket.

Pemilihan responden dintentukan dengan membandingkan nilai Kalkulus Lanjut yang sebenarnya dengan nilai Kalkulus Lanjut dari persamaan regresi dengan mengurangi nilai Kalkulus Lanjut yang sebenarnya 
dengan nilai Kalkulus Lanjut dari persamaan regresi atau residual yang dimisalkan $p$. Selanjutnya mahasiswa dibagi kedalam tiga kelompok. Dari sampel mahasiswa yang memperoleh nilai $p<-3,00$ sebanyak 25 mahasiswa, untuk nilai $p>3,00$ sebanyak 30 mahasiswa dan untuk nilai $-3,00 \leq p \leq 3,00$ sebanyak 32 orang. Diambil 10 responden dari masing - masing kelompok yang telah dibagi sebelumnya berdasarkan nilai residunya. Angket disebarkan mulai tanggal 14-21 April 2020. Berikut adalah rangkuman dari 30 responden tersebut.

Tabel 4. Rangkuman dari Penyebaran Angket

\begin{tabular}{|c|c|c|c|c|c|c|c|c|}
\hline Kelompok & Dosen & Materi & $\begin{array}{c}\text { Diri } \\
\text { Sendiri }\end{array}$ & $\begin{array}{c}\text { Dosen } \\
\text { \& } \\
\text { Materi }\end{array}$ & $\begin{array}{c}\text { Dosen \& } \\
\text { Diri } \\
\text { Sendiri }\end{array}$ & $\begin{array}{c}\text { Dosen \& } \\
\text { Lainnya } \\
\text { (Faktor } \\
\text { Teman) }\end{array}$ & $\begin{array}{c}\text { Dosen, Diri } \\
\text { Sendiri \& } \\
\text { Lainnya } \\
\text { (Faktor } \\
\text { Teman) } \\
\end{array}$ & Total \\
\hline 1 & 1 & 1 & 3 & 2 & 2 & 1 & - & 10 \\
\hline 2 & 4 & 1 & - & 4 & 1 & - & - & 10 \\
\hline 3 & 2 & & 1 & 3 & 3 & - & 1 & 10 \\
\hline Total & 7 & 2 & 4 & 9 & 6 & 1 & 1 & 30 \\
\hline Persentase & $23,3 \%$ & $6,7 \%$ & $13,3 \%$ & $30 \%$ & $20 \%$ & $3,3 \%$ & $3,3 \%$ & $100 \%$ \\
\hline
\end{tabular}

Berdasarkan hasil tersebut diperoleh faktor yang mempengaruhi hasil belajar Kalkulus Lanjut antara lain : Dosen dan materi (30\%), Dosen (23,3\%), Dosen dan diri sendiri (20\%), diri sendiri (13,3\%), materi (6,7\%), Dosen dan lainnya seperti faktor teman $(3,3 \%)$ dan Dosen, Diri Sendiri dan Lainnya seperti faktor teman $(3,3 \%)$. Berdasarkan hasil tersebut dapat disimpulkan bahwa Dosen memberi pengaruh yang besar seperti cara mengajar dan menilai yakni 24 dari 30 atau $80 \%$ responden berpendapat bahwa Dosen berpengaruh dalam hasil belajarnya.

\section{KESIMPULAN DAN SARAN}

Berdasarkan hasil dan pembahsan dapat ditarik kesimpulan sebagai berikut : (1) ada kontribusi yang signifikan antara hasil belajar Kalkulus Diferensial terhadap hasil belajar Kalkulus Lanjut (2) ada kontribusi yang signifikan antara hasil belajar Kalkulus Integral terhadap hasil belajar Kalkulus Lanjut (3) ada kontribusi yang signifikan antara hasil belajar Kalkulus Diferensial dan hasil belajar Kalkulus Integral terhadap hasil belajar Kalkulus Lanjut. Selain itu hasil belajar Kalkulus Integral memiliki pengaruh atau kontribusi yang lebih domain terhadap hasil belajar Kalkulus Lanjut dari pada hasil belajar Kalkulus Diferensial dan terdapat error yang cukup besar sebesar $46,7 \%$ sehingga menunjukkan ada pengaruh yang besar di luar hasil belajar Kalkulus Diferensial dan hasil belajar Kalkulus Integral. Hal ini didukung dengan hasil angket yang memperoleh bahwa ada faktor lain seperti dosen memberi pengaruh yang besar dalam hasil belajarnya.

Saran peneliti untuk mahasiswa agar mengikuti mata kuliah Kalkulus Diferensial dan Kalkulus Integral yang merupakan mata kuliah prasyarat dengan baik karena berpengaruh cukup besar terhadap hasil belajar mata kuliah Kalkulus Lanjut.

\section{UCAPAN TERIMA KASIH}

Ucapan terima kasih kepada Dr. Marcellinus Andy Rudhito yang telah membimbing penyusunan artikel ini dan Program Studi Pendidikan Matematika FKIP Universitas Sanata Dharma yang telah memberikan bantuan dana untuk mempresentasikan artikel ini dalam Seminar Nasional Sains dan Pendidikan Sains 2020 yang diselenggarakan oleh Fakultas Sains dan Matematika, Universitas Kristen Satya Wacana pada tanggal 19 Juni 2020.

\section{DAFTAR PUSTAKA}

Arsyad, A. (2005). Media Pembelajaran. Jakarta: PT RajaGrafindo Persada.

Rejeki, S. (2015). Kontribusi Kemampuan Kalkulus I dan Kalkulus II Terhadap Hasil Belajar Mata Kuliah Analisis Vektor. JPM IAIN Antasar, 3(1), 1-14.

Septian, A. (2014). Pengaruh Kemampuan Prasyarat terhadap Kemampuan Penalaran Matematika dalam Matakuliah Analisis Real. Jurnal Kajian Pendidikan, 4(2), 178-199. 
Soekamto, T. (1997). Teori Belajar dan Model-Model Pembelajaran. Jakarta: Dirjen Dikti Depdikbud.

SPSS Indonesia. (2020). Cara Menghitung SE dan SR dalam Analisis Regresi Linear Berganda. Retrieved from : www.spssindonesia.com

Sufren \& Natanael, Y. (2014). Belajar Otodidak SPSS Pasti Bisa. Jakarta: Elex Media Komputindo.

Sugiyono. (2013). Metode Penelitian Pendekatan Kuantitatif, Kualitatif, dan R\&D. Bandung: Alfabeta.

Supratiknya, A. (2012). Penilaian Hasil Belajar dengan Teknik Nontes. Yogyakarta: Universitas Sanata Dharma.

Suprijono, A. (2012). Cooperative Learning: Teori dan Aplikasi PAIKEM. Yogyakarta: Pustaka Pelajar.

Winarni, E. W. (2011). Penelitian Pendidikan. Bengkulu: Putri Media. 